\title{
BMJ
}

\section{The benefits of statins in people without established cardiovascular disease but with cardiovascular risk factors: meta-analysis of randomised controlled trials}

\author{
J J Brugts, doctor, ${ }^{1}$ T Yetgin, doctor, ${ }^{1}$ S E Hoeks, epidemiologist, ${ }^{1}$ A M Gotto, professor, doctor, ${ }^{2}$ J Shepherd, \\ professor, doctor, ${ }^{3}$ R G J Westendorp, professor, doctor, ${ }^{4}$ A J M de Craen, epidemiologist, ${ }^{4}$ R H Knopp, \\ professor, doctor, ${ }^{5} \mathrm{H}$ Nakamura, professor, doctor, ${ }^{6}$ P Ridker, professor, doctor, ${ }^{7}$ R van Domburg, \\ epidemiologist, ${ }^{1}$ J W Deckers, doctor ${ }^{1}$
}

Department of Cardiology, Erasmus MC Thoraxcenter, 3015 GD, Rotterdam, Netherlands

${ }^{2}$ Weill Medical College of Cornell University, NY, USA

3University of Glasgow, Scotland

${ }^{4}$ Department of Gerontology and

Geriatrics, Leiden University

Medical Center, Netherlands

${ }^{5}$ Department of Medicine and

Northwest Lipid Research Clinic, WA, USA

${ }^{6}$ Mitsukoshi Health and Welfare Foundation, Tokyo, Japan

${ }^{7}$ Brigham and Women's Hospital, Boston, MA, USA

Correspondence to: J J Brugts

j.brugts@erasmusmc.nl

Cite this as: BMJ 2009;338:b2376 doi:10.1136/bmj.b2376

\section{ABSTRACT}

Objectives To investigate whether statins reduce all cause mortality and major coronary and cerebrovascular events in people without established cardiovascular disease but with cardiovascular risk factors, and whether these effects are similar in men and women, in young and older ( 65 years) people, and in people with diabetes mellitus. Design Meta-analysis of randomised trials.

Data sources Cochrane controlled trials register, Embase, and Medline.

Data abstraction Two independent investigators identified studies on the clinical effects of statins compared with a placebo or control group and with followup of at least one year, at least $80 \%$ or more participants without established cardiovascular disease, and outcome data on mortality and major cardiovascular disease events. Heterogeneity was assessed using the $Q$ and $\mathrm{I}^{2}$ statistics. Publication bias was assessed by visual examination of funnel plots and the Egger regression test. Results 10 trials enrolled a total of 70388 people, of whom 23681 (34\%) were women and 16078 (23\%) had diabetes mellitus. Mean follow-up was 4.1 years.

Treatment with statins significantly reduced the risk of all cause mortality (odds ratio $0.88,95 \%$ confidence interval 0.81 to 0.96$)$, major coronary events $(0.70,0.61$ to 0.81$)$, and major cerebrovascular events $(0.81,0.71$ to 0.93$)$. No evidence of an increased risk of cancer was observed. There was no significant heterogeneity of the treatment effect in clinical subgroups.

Conclusion In patients without established cardiovascular disease but with cardiovascular risk factors, statin use was associated with significantly improved survival and large reductions in the risk of major cardiovascular events.

\section{INTRODUCTION}

Cardiovascular disease is the leading cause of death and disability in the Western world and contributes substantially to healthcare budgets. ${ }^{1}$ Several clinical trials and meta-analyses have shown the beneficial effects of lipid lowering treatment using hydroxylmethyl glutaryl coenzyme A reductase inhibitors (statins) in reducing mortality and cardiovascular morbidity in patients with established cardiovascular disease. ${ }^{2-6}$ Statins therefore have a place in the secondary prevention of cardiovascular disease. $^{7-10}$

The use of statins in patients without established cardiovascular disease (that is, primary prevention) and at relatively low risk has important public health implications. To date research has provided ambiguous answers. In addition, the reliability of treatment in older people ( $>65$ years), women, and those with diabetes mellitus is uncertain, mainly because of a lack of data or inconsistent findings within these clinically defined groups. ${ }^{112}$ Most meta-analyses have been carried out on published tabular data and failed to provide consistent answers on treatment effect in these subgroups. ${ }^{1314}$

We carried out a meta-analysis of randomised trials that focused on primary prevention to determine whether statins reduce all cause mortality and the incidence of major coronary and cerebrovascular events in people without established cardiovascular disease but with cardiovascular risk factors. We also assessed whether these effects differed by sex, age, and the presence of diabetes.

\section{METHODS}

We followed the quality of reporting of meta-analysis guidelines. ${ }^{15}$ We searched the Cochrane Central Register of Controlled Trials, Medline (1990-November 2008), Embase (1980-November 2008), DARE, and the ACP Journal Club for randomised clinical trials that compared statins with a control group in people without established cardiovascular disease but with cardiovascular risk factors. We identified relevant studies using the MeSH terms "HMG-CoA reductase inhibitor", "atorvastatin", "simvastatin", "pravastatin", "fluvastatin", "rosuvastatin", or "lovastatin", and "cardiovascular disease", "coronary heart disease", "cerebrovascular disease", or "myocardial infarction", 
and "cholesterol", "LDL" [low density lipoprotein], "HDL" [high density lipoprotein], or "triglycerides", and primary prevention restricted to randomised controlled trials or meta-analyses. In addition we examined the reference lists and related links of retrieved articles in PubMed to detect studies potentially eligible for inclusion.

\section{Study selection}

We included studies if they were randomised trials of statins compared with controls (placebo, active control, or usual care), had a mean follow-up of at least one year, reported on mortality or cardiovascular disease events as primary outcomes, and included at least $80 \%$ of people without established cardiovascular disease or reported data separately on a sole primary prevention group and provided specific numbers for patients and events in that group. Eight studies were excluded that primarily investigated statin related non-clinical and intermediate surrogate end points such as changes in the thickness of the carotid intima media and lipid levels that collectively contributed fewer than 50 clinical events. ${ }^{16-23}$ We also excluded one study in patients with renal transplants because of the specific nature of that population, ${ }^{24}$ and three studies with design problems, fewer than 20 events overall, and insufficient follow-up. ${ }^{25-27}$ Our study therefore focused on people without established cardiovascular disease but with cardiovascular risk factors.

\section{Validity assessment}

Our search identified 1230 studies, of which 10 fulfilled our inclusion criteria. ${ }^{\text {w1-w10 }}$ Figure 1 summarises the results of the search. We evaluated suitable trials for concealment of treatment allocation, performance of the analysis according to the intention to treat principle, and completeness of follow-up. The Jadad scale was used to score study quality (range 0-5, higher scores indicating better quality). ${ }^{28}$ Study quality was sufficient $(\geq 4)$ for all included randomised clinical trials.

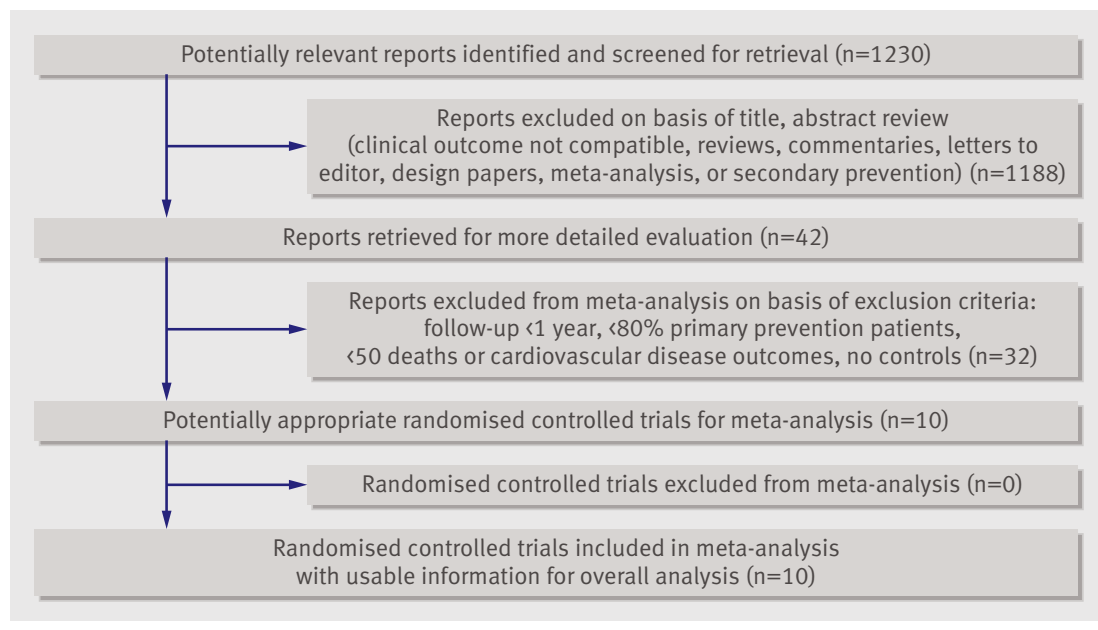

Fig 1| Flow of article selection in trial

\section{Data abstraction}

From each study two investigators separately extracted information on trial characteristics, patient data, outcome measures, and study quality using a standardised protocol and reporting document. Disagreements were resolved by consensus.

\section{Subgroup analysis}

We searched the papers for data on clinically defined subgroups. The Antihypertensive and Lipid-Lowering Treatment to Prevent Heart Attack Trial (ALLHAT) w7 presented data on our prespecified subgroups. The other studies did not publish results stratified by age ( $<65$ or $>65$ years), sex, or diabetes. To obtain data for these stratified groups we sent an electronic sheet with data fields to the principal investigators of these studies, requesting the number of events and number of patients in the treatment and placebo groups. We obtained data on subgroups for five trials. ${ }^{\text {w1-w3 } 6 \text { w8 }}$ Subgroup analyses were therefore done in six studies. ${ }^{\text {w1-w3 w6 w7 }}$ Not all end points were recorded in these studies.

\section{End points}

The primary end point of our meta-analysis was all cause mortality. Secondary end points were the composite of major coronary events defined as death from coronary heart disease and non-fatal myocardial infarction, and the composite of major cerebrovascular events defined as fatal and non-fatal stroke. We also assessed death from coronary heart disease, non-fatal myocardial infarction, revascularisations (percutaneous coronary intervention or coronary artery bypass graft), and cancer (fatal and non-fatal). The clinical outcomes evaluated in the subgroup analysis (data should be reported in two or more studies) were all cause mortality, major coronary events, major cerebrovascular events, and cancer.

\section{Quantitative data synthesis}

For each trial we calculated the summary odds ratios and $95 \%$ confidence intervals for the clinical outcomes. We pooled studies using both fixed effect and random effects models. ${ }^{29} \mathrm{~A}$ random effects model makes the assumption that individual studies are estimating different treatment effects. Our conclusions were drawn from the results of the random effects model. We were unable to exclude a small proportion of secondary prevention patients from the West of Scotland Coronary Prevention Study (1069/6595; WOSCOPS), ${ }^{\text {w9 }}$ ALLHAT $(1470 / 10355),{ }^{\text {w7 }}$ and the Anglo-Scandinavian Cardiac Outcomes Trial lipid lowering arm (1906/ 10305 ; ASCOT-LLA), ${ }^{\text {w10 }}$ and these therefore constitute about $6 \%$ of our study population $(4445 / 70388$ )..$^{30 w 7}$ w9 In a separate analysis we verified whether our results remained consistent after exclusion of these studies. We also investigated whether our results differed when we used the original study results from ASCOT without extended follow-up. ${ }^{30 w 10}$ 
We assessed the results for heterogeneity in the main analysis and subgroup analysis by examining the forest plots and then calculating a Q statistic, which we compared with a $\chi^{2}$ distribution, and the $\mathrm{I}^{2}$ index..$^{31}$ The $\mathrm{Q}$ test indicates the statistical significance of the homogeneity hypothesis and the $\mathrm{I}^{2}$ index measures the extent of the heterogeneity. We considered the results for heterogeneity to be significant at $\mathrm{P}<0.10$ (two sided). Publication bias was assessed for the main end points by visually examining for funnel plot

Table 1|Characteristics of included trials

\begin{tabular}{|c|c|c|c|c|c|c|c|c|c|c|}
\hline Characteristic & $\begin{array}{c}\text { WOSCOPS } \\
1995 \mathrm{wg}\end{array}$ & $\begin{array}{c}\text { AFCAPS/ } \\
\text { TexCAPS } \\
1998 w 8\end{array}$ & $\begin{array}{l}\text { PROSPER* } \\
\text { 2002w6 }\end{array}$ & $\begin{array}{l}\text { ALLHAT-LLT } \\
2002 \text { w7 }\end{array}$ & $\begin{array}{l}\text { ASCOT-LLA } \\
2003 w 10\end{array}$ & HPS* 2003w5 & $\begin{array}{l}\text { CARDS } \\
2004 w 4\end{array}$ & $\begin{array}{l}\text { ASPEN* } \\
2006 w_{3}\end{array}$ & MEGA 2006w2 & $\begin{array}{l}\text { JUPITER } \\
2008 \mathrm{w} 1\end{array}$ \\
\hline $\begin{array}{l}\text { Target } \\
\text { population }\end{array}$ & $\begin{array}{c}\text { Men with } \\
\text { hypercholes- } \\
\text { terolaemia (no } \\
\text { history of } \\
\text { myocardial } \\
\text { infarction) }\end{array}$ & $\begin{array}{l}\text { People with } \\
\text { average or } \\
\text { below average } \\
\text { cholesterol } \\
\text { levels (without } \\
\text { atherosclerotic } \\
\text { cardiovascular } \\
\text { disease) }\end{array}$ & $\begin{array}{l}\text { Elderly people } \\
\text { with } \\
\text { cardiovascular } \\
\text { risk factors }\end{array}$ & $\begin{array}{l}\text { People with } \\
\text { hypertension, } \\
\text { moderate } \\
\text { hypercholes- } \\
\text { terolaemia, } \\
\text { and at least } \\
\text { one coronary } \\
\text { heart disease } \\
\text { risk factor }\end{array}$ & $\begin{array}{l}\text { People with } \\
\text { hypertension, } \\
\text { average or } \\
\text { lower } \\
\text { cholesterol } \\
\text { levels, and at } \\
\text { least three } \\
\text { other risk } \\
\text { factors }\end{array}$ & $\begin{array}{c}\text { People with } \\
\text { diabetes }\end{array}$ & $\begin{array}{l}\text { People with } \\
\text { diabetes and } \\
\text { low density } \\
\text { lipoprotein } \\
\text { cholesterol (no } \\
\text { history of } \\
\text { cardiovascular } \\
\text { disease) }\end{array}$ & $\begin{array}{l}\text { People with } \\
\text { diabetes and } \\
\text { low density } \\
\text { lipoprotein } \\
\text { cholesterol } \\
\text { levels below } \\
\text { guideline } \\
\text { targets }\end{array}$ & $\begin{array}{l}\text { People with } \\
\text { hypercholes- } \\
\text { terolaemia and } \\
\text { no history of } \\
\text { coronary heart } \\
\text { disease or } \\
\text { stroke }\end{array}$ & $\begin{array}{l}\text { People without } \\
\text { vascular } \\
\text { disease, low } \\
\text { density } \\
\text { lipoprotein } \\
\text { cholesterol } \\
\langle 130 \mathrm{mg} / \mathrm{dl} \text {, and } \\
\text { high sensitivity } \\
\text { C reactive } \\
\text { protein > } \\
2.0 \mathrm{mg} / \mathrm{l}\end{array}$ \\
\hline Design & $\begin{array}{l}\text { Randomised } \\
\text { double blind } \\
\text { placebo } \\
\text { controlled trial }\end{array}$ & $\begin{array}{l}\text { Randomised } \\
\text { double blind } \\
\text { placebo } \\
\text { controlled trial }\end{array}$ & $\begin{array}{l}\text { Randomised } \\
\text { double blind } \\
\text { placebo } \\
\text { controlled trial }\end{array}$ & $\begin{array}{c}\text { Randomised } \\
\text { controlled trial } \\
\text { (control=usual } \\
\text { care) }\end{array}$ & $\begin{array}{l}\text { Randomised } \\
\text { double blind } \\
\text { placebo } \\
\text { controlled trial }\end{array}$ & $\begin{array}{l}\text { Randomised } \\
\text { double blind } \\
\text { placebo } \\
\text { controlled trial }\end{array}$ & $\begin{array}{l}\text { Randomised } \\
\text { double blind } \\
\text { placebo } \\
\text { controlled trial }\end{array}$ & $\begin{array}{l}\text { Randomised } \\
\text { double blind } \\
\text { placebo } \\
\text { controlled trial }\end{array}$ & $\begin{array}{l}\text { Randomised } \\
\text { double blind } \\
\text { placebo } \\
\text { controlled trial } \\
\text { (control=diet) }\end{array}$ & $\begin{array}{l}\text { Randomised } \\
\text { double blind } \\
\text { placebo } \\
\text { controlled trial }\end{array}$ \\
\hline $\begin{array}{l}\text { No of } \\
\text { participants } \\
\text { (statin/control) }\end{array}$ & $\begin{array}{c}6595(3302 / \\
3293)\end{array}$ & $\begin{array}{c}6605(3304 / \\
3301)\end{array}$ & $\begin{array}{c}3239(1585 / \\
1654)\end{array}$ & $\begin{array}{c}10355(5170 / \\
5185)\end{array}$ & $\begin{array}{c}10305(5168 / \\
5137)\end{array}$ & $\begin{array}{c}2912(1455 / \\
1457)\end{array}$ & $\begin{array}{c}2838(1428 / \\
1410)\end{array}$ & $\begin{array}{c}1905(959 / \\
946)\end{array}$ & $\begin{array}{c}7832(3866 / \\
3966)\end{array}$ & $\begin{array}{c}17802(8901 / \\
8901)\end{array}$ \\
\hline $\begin{array}{l}\text { Mean follow-up } \\
\text { (years) }\end{array}$ & 4.9 & 5.2 & 3.2 & 4.8 & $5.5 \dagger$ & 4.8 & $3.9 \dagger$ & $4.0 \dagger$ & 5.3 & $1.9 \dagger$ \\
\hline Drug & Pravastatin & Lovastatin & Pravastatin & Pravastatin & Atorvastatin & Simvastatin & Atorvastatin & Atorvastatin & Pravastatin & Rosuvastatin \\
\hline Dose (mg/day) & 40 & $20-40$ & 40 & $20-40$ & 10 & 40 & 10 & 10 & 1020 & 20 \\
\hline $\begin{array}{l}\text { Mean age } \\
\text { (range) (years) }\end{array}$ & $55.3(45-64)$ & $58(45-73)$ & $75(70-82)$ & $66.4(51-81)$ & $63.1(40-79)$ & NA $(40-80)$ & $61.5(40-75)$ & $60.5(40-75)$ & $58.3(40-70)$ & $66 †(60-71)$ \\
\hline Women (\%) & 0 & 15 & $58 \ddagger$ & 49 & 18.9 & NA & 32 & 38 & 68.4 & 37.9 \\
\hline $\begin{array}{l}\text { With diabetes } \\
(\%)\end{array}$ & 1 & 3.8 & $12.2 \ddagger$ & 34.4 & 24.3 & 100 & 100 & 100 & 21 & 0 \\
\hline $\begin{array}{l}\text { Current smoker } \\
\text { (\%) }\end{array}$ & 44 & 13 & $33.4 \ddagger$ & 23.3 & 33.2 & NA & 22 & 12 & 21 & 16 \\
\hline $\begin{array}{l}\text { Hypertension } \\
(\%)\end{array}$ & 16 & 22 & $71.6 \ddagger$ & 89.9 & 80.3 & NA & 84 & 52 & 42 & 0 \\
\hline $\begin{array}{l}\text { Mean body } \\
\text { mass index }\end{array}$ & 26 & 26.8 & $27 \ddagger$ & 29.9 & 28.6 & NA & 28.7 & 28.9 & 23.8 & $28.4 \dagger$ \\
\hline $\begin{array}{l}\text { Mean systolic } \\
\text { blood pressure } \\
(\mathrm{mm} \mathrm{Hg})\end{array}$ & 136 & 138 & $156.6 \ddagger$ & 145 & 164.2 & NA & 144 & 133 & 132 & $134 \dagger$ \\
\hline $\begin{array}{l}\text { Mean diastolic } \\
\text { blood pressure } \\
(\mathrm{mm} \mathrm{Hg})\end{array}$ & 84 & 78 & $85.2 \ddagger$ & 84 & 95 & NA & 83 & 77.1 & 78.4 & $80 \dagger$ \\
\hline
\end{tabular}

Baseline lipid

levels (mmol/l)

(\% change):

\begin{tabular}{|c|c|c|c|c|c|c|c|c|c|c|}
\hline $\begin{array}{l}\text { Total } \\
\text { cholesterol }\end{array}$ & $7.0(-20.0)$ & $5.7(-19.3)$ & 5.7 (NA) & $5.9(-9.6)$ & $5.5(-18.2)$ & NA & $5.4(-21.8)$ & $5.0(-19.8)$ & $6.3(-11.0)$ & 4.8 (NA) \\
\hline $\begin{array}{l}\text { Low density } \\
\text { lipoprotein } \\
\text { cholesterol }\end{array}$ & $5.0(-26.0)$ & $3.9(-26.5)$ & 3.8 (NA) & $3.8(-16.7)$ & $3.4(-27.6)$ & NA & $3.0(-33.9)$ & $3.0(-30.5)$ & $4.0(-18.0)$ & $2.8(N A)$ \\
\hline $\begin{array}{l}\text { High density } \\
\text { lipoprotein } \\
\text { cholesterol }\end{array}$ & $1.1(5.0)$ & $1.0(4.8)$ & 1.3 (NA) & $1.2(0.9)$ & $1.3(1.5)$ & NA & $1.4(4.0)$ & $1.2(1.9)$ & $1.5(5.0)$ & $1.3(\mathrm{NA})$ \\
\hline Triglycerides & $1.8(-12.0)$ & $1.7(-12.7)$ & $1.5(\mathrm{NA})$ & $1.7(0.0)$ & $1.7(-12.6)$ & NA & $2.0(-15.9)$ & $1.6(-4.7)$ & $1.4(-7.0)$ & 1.3 (NA) \\
\hline
\end{tabular}

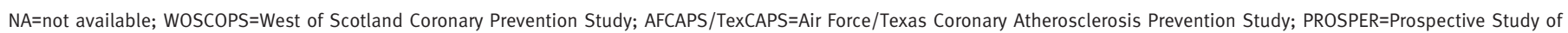

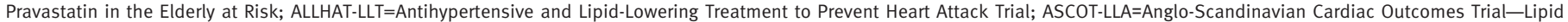

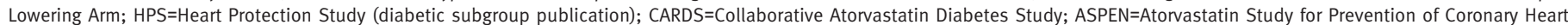

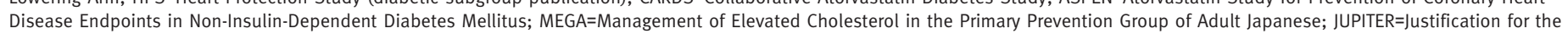
Use of Statins in Prevention: an Intervention Trial Evaluating Rosuvastatin.

*Primary prevention subgroup data used.

†Median; in ASCOT-LLA data were from extended observations trial. ${ }^{\text {w10 }}$

$\ddagger$ Data from baseline characteristics publication of PROSPER. ${ }^{33}$ 
All cause mortality

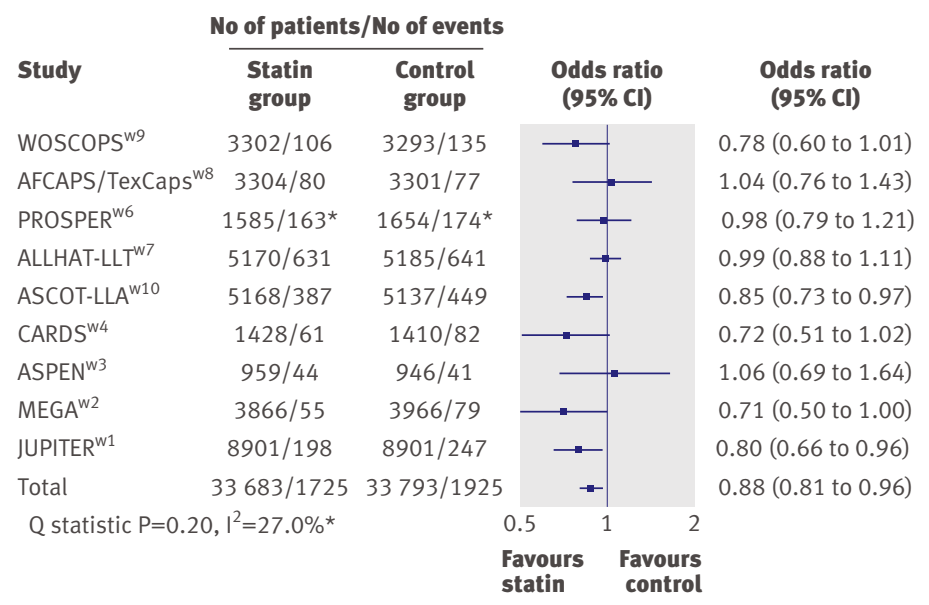

Major cerebrovascular events

\begin{tabular}{|c|c|c|}
\hline \multirow[b]{2}{*}{ Study } & \multicolumn{2}{|c|}{ No of patients/No of events } \\
\hline & $\begin{array}{l}\text { Statin } \\
\text { group }\end{array}$ & $\begin{array}{l}\text { Control } \\
\text { group }\end{array}$ \\
\hline WOSCOPS ${ }^{\text {w9 }}$ & $3302 / 46$ & $3293 / 51$ \\
\hline AFCAPS/TexCaps ${ }^{\text {w8 }}$ & $3304 / 14$ & $3301 / 17$ \\
\hline PROSPER $^{\text {w6 }}$ & $1585 / 61$ & $1654 / 62$ \\
\hline ALLHAT-LLT'W7 & $5170 / 209$ & $5185 / 231$ \\
\hline ASCOT-LLA ${ }^{\mathrm{w} 10}$ & $5168 / 166$ & $5137 / 212$ \\
\hline CARDS $^{\mathrm{w} 4}$ & $1428 / 21$ & $1410 / 39$ \\
\hline ASPEN $^{\mathrm{W} 3}$ & $959 / 27$ & $946 / 29$ \\
\hline $\mathrm{MEGA}^{\mathrm{w} 2}$ & $3866 / 50$ & $3966 / 62$ \\
\hline JUPITER ${ }^{W 1}$ & $8901 / 33$ & $8901 / 64$ \\
\hline Total & $33683 / 627$ & $33793 / 767$ \\
\hline
\end{tabular}

$Q$ statistic $P=0.23, \mathrm{I}^{2}=24.0 \%$ *

$\begin{array}{llll}0.25 & 0.5 & 1 & 2\end{array}$

\section{Major coronary events}

\begin{tabular}{|c|c|c|c|c|}
\hline \multirow[b]{2}{*}{ Study } & \multicolumn{2}{|c|}{ No of patients/No of events } & \multirow[b]{2}{*}{$\begin{array}{c}\text { Odds ratio } \\
(95 \% \mathrm{Cl})\end{array}$} & \multirow[b]{2}{*}{$\begin{array}{c}\text { Odds ratio } \\
(95 \% \mathrm{CI})\end{array}$} \\
\hline & $\begin{array}{l}\text { Statin } \\
\text { group }\end{array}$ & $\begin{array}{l}\text { Control } \\
\text { group }\end{array}$ & & \\
\hline WOSCOPS $^{\text {w9 }}$ & $3302 / 174$ & $3293 / 248$ & $\rightarrow$ & 0.68 (0.56 to 0.83$)$ \\
\hline AFCAPS/TexCaps ${ }^{\text {w8 }}$ & $3304 / 57^{*}$ & $3301 / 95^{*}$ & $\rightarrow$ & $0.61(0.45$ to 0.83$)$ \\
\hline PROSPER $^{w 6}$ & $1585 / 126$ & $1654 / 145$ & $\rightarrow$ & $0.90(0.70$ to 1.15$)$ \\
\hline ALLHAT-LLT ${ }^{\mathrm{w} 7}$ & $5170 / 380$ & $5185 / 421$ & $\rightarrow$ & $0.90(0.78$ to 1.04$)$ \\
\hline ASCOT-LLA ${ }^{\text {w10 }}$ & $5168 / 163$ & $5137 / 249$ & $\rightarrow$ & $0.64(0.52$ to 0.78$)$ \\
\hline $\mathrm{HPS}^{\mathrm{W} 5}$ & $1455 / \mathrm{NA}$ & $1457 / N A$ & $\longrightarrow$ & 0.57 (0.41 to 0.79 \\
\hline CARDS $^{\mathrm{w} 4}$ & $1428 / 43$ & $1410 / 65$ & $\longrightarrow$ & 0.65 (0.44 to 0.97$)$ \\
\hline $\mathrm{MEGA}^{\mathrm{w} 2}$ & $3866 / 23 \dagger$ & $3966 / 43 \dagger$ & $\longrightarrow$ & $0.55(0.33$ to 0.91$)$ \\
\hline Total & $23823 / 966$ & $23946 / 1266$ & - & $0.70(0.61$ to 0.81$)$ \\
\hline \multirow{2}{*}{\multicolumn{2}{|c|}{$Q$ statistic $P=0.02, I^{2}=60.0 \%$ * }} & & 0.51 & \\
\hline & & \multicolumn{2}{|c|}{$\begin{array}{ll}\text { Favours } & \text { Favours } \\
\text { statin } & \text { control }\end{array}$} & \\
\hline
\end{tabular}

Cancer

\begin{tabular}{|c|c|c|c|c|}
\hline \multirow[b]{2}{*}{ Study } & \multicolumn{2}{|c|}{ No of patients/No of events } & \multirow[b]{2}{*}{$\begin{array}{c}\text { Odds ratio } \\
(95 \% \mathrm{Cl})\end{array}$} & \multirow[b]{2}{*}{$\begin{array}{l}\text { Odds ratio } \\
(95 \% \mathrm{Cl})\end{array}$} \\
\hline & $\begin{array}{l}\text { Statin } \\
\text { group }\end{array}$ & $\begin{array}{l}\text { Control } \\
\text { group }\end{array}$ & & \\
\hline WOSCOPS ${ }^{\text {w9 }}$ & $3302 / 44$ & $3293 / 49$ & - & 1.09 (0.84 to 1.43$)$ \\
\hline AFCAPS/TexCaps ${ }^{\text {w8 }}$ & $8304 / 252$ & $3301 / 259$ & $\rightarrow$ & $0.97(0.81$ to 1.16$)$ \\
\hline ALLHAT-LLT ${ }^{\mathrm{w} 7}$ & $5170 / 378$ & $5185 / 369$ & - & 1.03 (0.89 to 1.19$)$ \\
\hline CARDS $^{\text {w4 }}$ & $1428 / 20$ & $1410 / 30$ & - & 0.65 (0.37 to 1.16$)$ \\
\hline $\mathrm{MEGA}^{\mathrm{W} 2}$ & $3866 / 119$ & $3966 / 126$ & $\rightarrow$ & 0.97 (0.75 to 1.25$)$ \\
\hline JUPITER ${ }^{w 1}$ & $8901 / 333$ & $8901 / 372$ & $\rightarrow$ & 0.89 (0.77 to 1.04$)$ \\
\hline Total & $25971 / 1146$ & $26056 / 1205$ & $\rightarrow$ & 0.97 (0.89 to 1.05$)$ \\
\hline \multirow{2}{*}{\multicolumn{2}{|c|}{$Q$ statistic $P=0.61, I^{2}=0 \% *$}} & & 0.5 & \\
\hline & & \multicolumn{2}{|c|}{$\begin{array}{l}\text { Favours } \begin{array}{l}\text { Favours } \\
\text { statin }\end{array} \text { contro }\end{array}$} & \\
\hline
\end{tabular}

Favours Favours

statin control

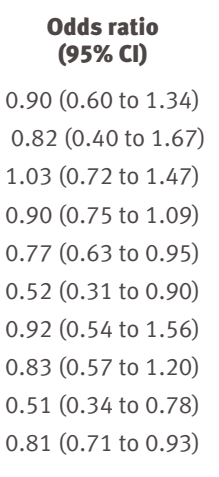

\section{$(95 \% \mathrm{Cl})$}
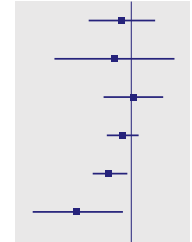

$\longrightarrow \quad 0.92$ (0.54 to 1.56$)$

$0.81(0.71$ to 0.93$)$

statin

Fig 2 Odds ratios (95\% confidence intervals) for all cause mortality, major coronary events, major cerebrovascular events, and incidence of cancer. (Mortality risk based on mean follow-up of 4.1 years, with data from nine trials, and 67476 patients free of cardiovascular disease (no data available from HPS diabetic $\mathrm{arm}^{\mathrm{w} 5}$ ). Risk of coronary events based on mean follow-up of 4.9 years, with data from eight trials, and 50681 patients free of cardiovascular disease (no data available from ASPEN $^{\text {w3 }}$ and JUPITER ${ }^{\mathrm{w} 1}$ ). Risk of cerebrovascular events based on mean follow-up of 4.1 years, with data from nine trials, and 67476 patients free of cardiovascular disease (no data available from HPS diabetic arm). Risk of cancer based on mean follow-up of 3.9 years, with data from six trials, and 52027 patients free of cardiovascular disease (no data available from HPS, ASCOT, ${ }^{\text {w10 }}$ PROSPER, ${ }^{\text {w6 }}$ and ASPEN). See footnote to table 1 for full titles of studies. *Measures of heterogeneity

asymmetry and quantified by using the Egger regression test to calculate two tailed P values. ${ }^{32}$

\section{RESULTS}

Table 1 shows the characteristics of the 10 included studies. ${ }^{\text {w1-w10 }}$ In total, 70388 participants were randomised, of whom 35138 were allocated to statin therapy and 35250 to control. The number of participants in the trials ranged from 1905 to 17802 . The mean age was 63 years (range 55.3 to 75.0), and the mean followup was 4.1 years (range 1.9 to 5.3). Thirty four per cent of participants were women and $23 \%$ had diabetes. The mean baseline low density lipoprotein cholesterol level was $3.63 \mathrm{mmol} / \mathrm{l}$. The mean reduction in levels of total cholesterol was $17.1 \%$, low density lipoprotein cholesterol was $25.6 \%$, and triglyceride was 9.3\%. High density lipoprotein cholesterol increased by a mean $3.3 \%$.
Mortality, coronary events, and cerebrovascular events

During a mean follow-up of 4.1 years 5.7\% (1925/ 33 793) of participants died in the control group compared with 5.1\% (1725/33 683) in the statin group. Statin therapy was therefore associated with a $12 \%$ risk reduction in all cause mortality compared with the control (odds ratio $0.88,95 \%$ confidence interval 0.81 to 0.96; fig 2 and table 2). The annual rate for all cause mortality with placebo in our study was $1.4 \%$ (fig 2). Overall, 5.4\% (1266/23 946) of participants in the control group had a major coronary event compared with $4.1 \%(966 / 23823)$ in the statin group, a 30\% risk reduc tion (odds ratio $0.70,95 \%$ confidence interval 0.61 to 0.81 ). The annual rate for major coronary events with placebo in our study was $1.1 \%$ (fig 2). Overall, $2.3 \%$ (767/33 793) of participants in the control group had a major cerebrovascular event compared with $1.9 \%$ $(627 / 33683)$ in the statin group, a 19\% risk reduction 
$(0.81,0.71$ to 0.93$)$. The annual rate for major cerebrovascular events with placebo in our study was $0.6 \%$ (fig 2). The annual rate for coronary heart disease mortality with placebo in our study was $0.3 \%$, for non-fatal myocardial infarction it was $0.6 \%$, for revascularisation it was $0.6 \%$, and for incidence of cancer it was $1.2 \%$. The association between statin therapy and risk of cancer was not significant $(0.97,0.89$ to 1.05 ; fig 2 and table 2). Table 2 also shows the summary odds ratios for other end points.

The outcome of the analyses was not influenced by removal of the three trials that enrolled 4445 patients $(6 \%)$ with a previous cardiovascular event (all cause mortality odds ratio $0.87,95 \%$ confidence interval 0.78 to 0.97 ). Also, using only the first reported data from ASCOT-LLA instead of the extended follow-up data that were published later did not influence the result of the analyses $(0.88,0.81$ to 0.97$) .{ }^{\text {w10 }}$ When the only study (Justification for the Use of Statins in Prevention: an Intervention Trial Evaluating Rosuvastatin; JUPITER) ${ }^{\mathrm{w} 1}$ that found a significant effect on mortality was removed from the analysis, the reduction in mortality in the other nine trials remained significant $(0.89,0.81$ to 0.97$)$.

No funnel plot asymmetry was visualised for the main end points, and $\mathrm{P}$ values using the Egger regression test were greater than 0.10 for all the major end points (all cause mortality: intercept $-0.8,95 \%$ confidence interval -3.1 to $1.5 ; \mathrm{P}$ value 0.42 ).

\section{Subgroup analyses}

No heterogeneity in treatment effect was observed for end points in men and women and for age $(\leq 65$ and $>65$ years) or diabetic status (fig 3 ).

\section{DISCUSSION}

The current meta-analysis totalled 70388 participants without established cardiovascular disease but with cardiovascular risk factors who were randomised to statin therapy or control. Statin therapy was associated with a significant risk reduction in all cause mortality of $12 \%$, in major coronary events of $30 \%$, and in major cerebrovascular events of $19 \%$. Moreover, statin use was not associated with an increased risk of cancer. These results are in line with those previously published on the effects of statins in secondary prevention. ${ }^{56}$

Our meta-analysis differs from earlier analyses in several ways. ${ }^{1314} \mathrm{We}$ were able to include several recently published studies targeted at primary prevention that enrolled a large number of women and people with diabetes. ${ }^{\text {w1-w3 }}$ For example, the Management of Elevated Cholesterol in the Primary Prevention Group of Adult Japanese trial (MEGA) ${ }^{\text {w2 }}$ comprised a large number of women $(68 \%, 5356 / 7832)$, and we were able to obtain subgroup data. Additionally, the Atorvastatin Study for Prevention of Coronary Heart Disease Endpoints in Non-Insulin-Dependent Diabetes Mellitus study (ASPEN) ${ }^{\text {w3 }}$ was carried out in a large group of people with type 2 diabetes $(n=1905)$ who did not have established cardiovascular disease. We also included data from the recently published JUPITER trial, ${ }^{\text {w1 }}$ totalling 17802 participants with no apparent vascular disease, low density lipoprotein cholesterol levels less than $3.4 \mathrm{mmol} / \mathrm{l}$, and increased levels of high sensitivity $\mathrm{C}$ reactive protein $(>2.0 \mathrm{mg} / \mathrm{l}) .{ }^{\mathrm{w} 1}$ As our study is based on such large numbers, this meta-analysis, including the subgroups, has significant statistical power. Previously, only the JUPITER trial showed improved survival associated with

Table 2 | Treatment effects of statin therapy. Values are odds ratios (95\% confidence intervals)

\begin{tabular}{|c|c|c|c|c|c|c|c|}
\hline Source & All cause mortality & $\begin{array}{l}\text { Major coronary } \\
\text { events }\end{array}$ & $\begin{array}{c}\text { Major } \\
\text { cerebrovascular } \\
\text { events }\end{array}$ & $\begin{array}{l}\text { Coronary heart } \\
\text { disease mortality }\end{array}$ & $\begin{array}{l}\text { Non-fatal } \\
\text { myocardial } \\
\text { infarction }\end{array}$ & Revascularisations & $\begin{array}{l}\text { Fatal or non-fatal } \\
\text { cancer }\end{array}$ \\
\hline WOSCOPS ${ }^{w 9}$ & 0.78 (0.60 to 1.01$)$ & 0.68 (0.56 to 0.83$)$ & $0.90(0.60$ to 1.34$)$ & $0.73(0.48$ to 1.11$)$ & $0.69(0.55$ to 0.85$)$ & 0.63 (0.44 to 0.90$)$ & 1.09 (0.84 to 1.43$)$ \\
\hline AFCAPS/TexCAPS ${ }^{w 8}$ & $1.04(0.76$ to 1.43$)$ & 0.61 (0.45 to 0.83$)$ & $0.82(0.40 \text { to } 1.67)^{\star}$ & $0.73(0.34$ to 1.60$)$ & NR & $0.69(0.55$ to 0.86$)$ & $0.97(0.81$ to 1.16$)$ \\
\hline PROSPER $^{w 6}$ & $0.98(0.79 \text { to } 1.21)^{*}$ & $0.90(0.70$ to 1.15$)$ & $1.03(0.72$ to 1.47$)$ & NR & NR & $0.82(0.54 \text { to } 1.25)^{\star}$ & NR† \\
\hline ALLHAT-LLT ${ }^{\mathrm{w} 7}$ & $0.99(0.88$ to 1.11$)$ & $0.90(0.78$ to 1.04$)$ & $0.90(0.75$ to 1.09$)$ & $0.99(0.79$ to 1.24$)$ & NR & NR & 1.03 (0.89 to 1.19$)$ \\
\hline ASCOT-LLA ${ }^{\mathrm{w} 10}$ & 0.85 (0.73 to 0.97$)$ & $0.64(0.52$ to 0.78$)$ & 0.77 (0.63 to 0.95$)$ & NR & NR & NR & NR \\
\hline HPS $^{\text {w5 }}$ & NR & $0.57(0.41 \text { to } 0.79)^{\star}$ & NR & NR & NR & NR & NR \\
\hline CARDS $^{\mathrm{w} 4}$ & $0.72(0.51$ to 1.02$)$ & 0.65 (0.44 to 0.97$)$ & $0.52(0.31$ to 0.90$)$ & $0.74(0.40$ to 1.36$)$ & $0.59(0.36$ to 0.98$)$ & $0.69(0.41$ to 1.17$)$ & $0.65(0.37$ to 1.16$)$ \\
\hline ASPEN $^{\text {w3 }}$ & $1.06(0.69$ to 1.64$)$ & NR & $0.92(0.54$ to 1.56$)$ & NR & NR & $0.92(0.60$ to 1.40$)$ & NR \\
\hline MEGA $^{\text {w2 }}$ & $0.71(0.50$ to 1.00$)$ & 0.55 (0.33 to 0.91$)$ & $0.83(0.57$ to 1.20$)$ & $0.55(0.22$ to 1.38$)$ & $0.55(0.30$ to 1.00$)$ & $0.60(0.40$ to 0.90$)$ & $0.97(0.75$ to 1.25$)$ \\
\hline JUPITER ${ }^{w 1}$ & 0.80 (0.66 to 0.96$)$ & NR & 0.51 (0.34 to 0.78$)$ & NR & 0.35 (0.22 to 0.58$)$ & 0.54 (0.40 to 0.72$)$ & 0.89 (0.77 to 1.04$)$ \\
\hline $\begin{array}{l}\text { All trials fixed effects } \\
\text { model }\end{array}$ & $0.90(0.84$ to 0.96$)$ & 0.74 (0.68 to 0.81$)$ & $0.82(0.74$ to 0.91$)$ & $0.88(0.73$ to 1.05$)$ & $0.61(0.52$ to 0.73$)$ & $0.67(0.59$ to 0.76$)$ & $0.97(0.89$ to 1.05$)$ \\
\hline $\begin{array}{l}\text { All trials random } \\
\text { effects model }\end{array}$ & 0.88 (0.81 to 0.96$)$ & 0.70 (0.61 to 0.81$)$ & 0.81 (0.71 to 0.93$)$ & $0.88(0.73$ to 1.05$)$ & $0.56(0.41$ to 0.76$)$ & 0.67 (0.59 to 0.76$)$ & 0.97 (0.89 to 1.05$)$ \\
\hline \multicolumn{8}{|l|}{ Heterogeneity: } \\
\hline Q statistic & 0.20 & $0.02 \ddagger$ & 0.23 & 0.49 & 0.11 & 0.48 & 0.61 \\
\hline $1^{2}$ index & Low (27\%) & Moderate (60\%) & Low (24\%) & Low $(0 \%)$ & Moderate (50\%) & Low (0\%) & Low $(0 \%)$ \\
\hline
\end{tabular}

NR=not reported. See footnote to table 1 for full titles of studies.

*Data from Thavendiranathan et al. ${ }^{14}$ Fixed effect and random effect models in meta-analysis gave almost identical results, making important statistical heterogeneity unlikely.

†No data in primary prevention group $(\mathrm{n}=3239) .{ }^{\text {w6 }}$

¥Significant heterogeneity; however, a positive trend of statin therapy is observed in all trials, only of different magnitude (no neutral or negative trials). 
All cause mortality

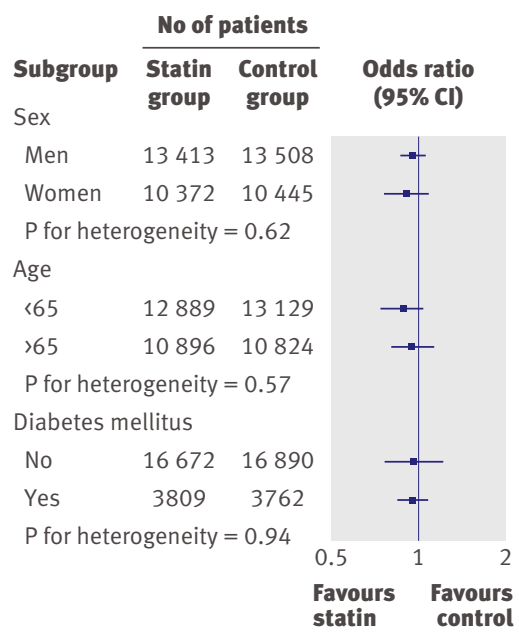

Major cerebrovascular events

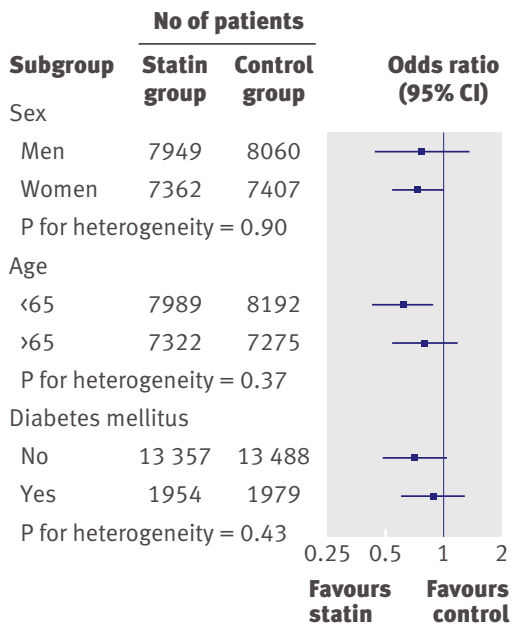

Major coronary events
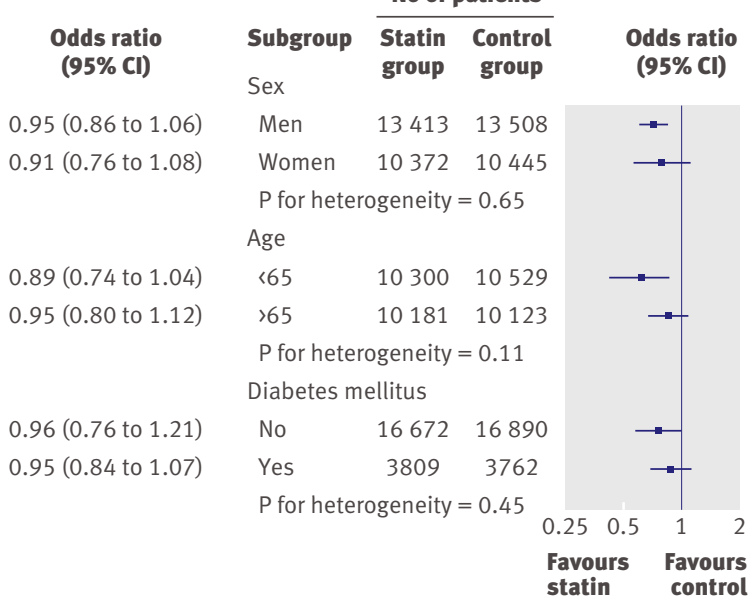

Cancer

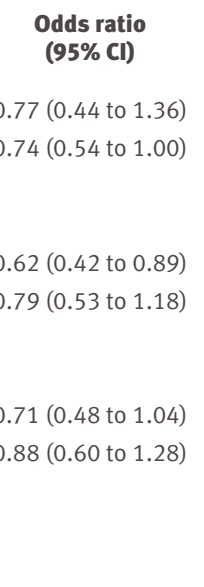

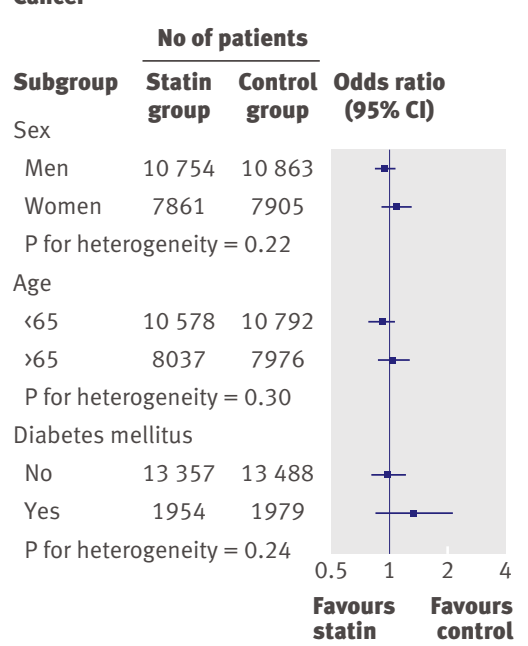

Odds ratio (95\% Cl)

$0.72(0.61$ to 0.86$)$ 0.79 (0.56 to 1.13$)$

$0.62(0.42$ to 0.87$)$ 0.86 (0.67 to 1.09$)$

0.76 (0.57 to 1.01$)$ 0.88 (0.69 to 1.13$)$

Fig 3 | Odds ratios (95\% confidence intervals) for clinically defined subgroups of sex, age, and diabetes for end points of all cause mortality, major coronary events, major cerebrovascular events, and cancer. Subgroup data are obtained from AFCAPS, w8 PROSPER, ${ }^{\mathrm{w} 6}$ ASPEN, ${ }^{\mathrm{w} 3}$ MEGA, ${ }^{\mathrm{w} 2}$ and JUPITER ${ }^{\mathrm{w} 1}$, and for mortality and coronary events from ALLHAT-LLT. ${ }^{\mathrm{w} 7}$ We had complete mortality data from all six trials for sex; for age, no data from PROSPER on age 655; for diabetes, no data from ASPEN and AFCAPS on participants without diabetes, and no data from AFCAPS and JUPITER on participants with diabetes. For cardiovascular events, studies included in subgroup analysis were same as for mortality, except no data from AFCAPS for age groups. For cerebrovascular disease, no data from AFCAPS and ALLHAT for all subgroups; also no data from PROSPER on age ८65, from ASPEN for participants without diabetes, and from JUPITER for participants with diabetes. For cancer no subgroup data were obtained from ALLHAT; also no data for age 165 from PROSPER, for participants without diabetes from AFCAPS and ASPEN, and for participants with diabetes from JUPITER and AFCAPS. See footnote to table 1 for full titles of studies

statin use in high risk participants, but it is clear from the current analysis that a mortality benefit is a shared characteristic of long term statin use in people without previous cardiovascular disease. The currently observed benefit, a $12 \%$ risk reduction in mortality, may even be an underestimation of the true effect because subsequent death after a morbid cardiovascular event was not always considered in individual trials.

The numbers and duration of follow-up of our study allow for relatively strong inferences on risk of cancer with long term statin use. We found no evidence for an increased risk of cancer, fatal or non-fatal. One of the trials (Prospective Study of Pravastatin in the Elderly at
Risk; PROSPER) ${ }^{\mathrm{w} 6}$ did report an increased risk of cancer with use of statins among men and women older than 70. Although our results show that statins do not seem to increase the risk of cancer, longer follow-up would be helpful to determine whether new cancer events could occur with time. This is especially critical when statins are used in primary prevention. Followup of patients in WOSCOPS for 10 years did not show higher rates of malignancies. ${ }^{3435}$ Concerns might remain about the higher risk of cancer in elderly patients (70-82 years) as in PROSPER, ${ }^{\text {w6 }}$ and further follow-up studies in such patients are required. Although this meta-analysis cannot fully remove that uncertainty, it confirms that the risk of cancer is not 


\section{WHAT IS ALREADY KNOWN ON THIS TOPIC}

Statins are effective in patients with established cardiovascular disease (secondary

prevention) but whether the benefits apply to primary prevention is unknown

Research has provided ambiguous answers on statin use in people at relatively lower risk

Furthermore, the efficacy of statins in subgroups of people aged more than 65 , women, and those with diabetes mellitus is debated

\section{WHAT THIS STUDY ADDS}

Statins improve survival and reduce the risk of major cardiovascular and cerebrovascular events in people without established cardiovascular disease

No significant differences in treatment effect of statins were observed in clinically defined groups for age, sex, and diabetes status

People at increased risk for cardiovascular disease should not be denied the relative benefits of long term statin use

\section{Clinical implications}

Our meta-analysis shows that the relative risk reduction from long term statin use in a primary care setting is comparable to that observed in secondary prevention. Our findings confirm the results of JUPITER ${ }^{\mathrm{w}}$ regarding the beneficial effect of statins on survival across a broader range of patients $(n=70388)$ at different levels of risk, and show that there is no significant difference in treatment benefit across a range of clinically defined groups (men and women, elderly people, and those with diabetes). Although our study population comprised participants without established cardiovascular disease, the pooled risk was high. The overall annual mortality was in the range of $1.4 \%$, and fatal as well as non-fatal cardiac and cerebrovascular events occurred at an annual rate of about $1.1 \%$ and $0.6 \%$, respectively. This is not too different from the event rates reported in trials of patients at relatively low risk in secondary prevention-for example, the European trial on reduction of cardiac events with perindopril in stable coronary artery disease and the Prevention of Events with Angiotensin-Converting Enzyme inhibition trial (PEACE) ${ }^{3637}$ Statin based secondary prevention is considered mandatory in participants in PEACE. Still, the absolute overall treatment benefit observed in the current study population would certainly be less than $1 \%$, and significant numbers of participants would need to be treated to prevent one event. From the currently pooled data it is not possible to exactly define one group of people who would benefit most from long term statin use. From current risk scoring systems, as well from current data, it is obvious that older men $(>65$ years) with risk factors, or older women with diabetes and risk factors, constitute the highest risk group. In view of the large treatment effects described here, it is likely that a considerable number of such people would benefit from long term statin use at reasonable costs. The correct identification of such people remains a challenge and, in addition to the assessment on the future cardiovascular risk based on standard cardiovascular risk factors, auxiliary diagnostic or prognostic assessments to improve risk prediction could be useful to identify these men and women more accurately. Given the favourable effects of long term statin treatment it would be wrong to deny these benefits to people at increased risk for cardiovascular disease.

Contributors: All authors contributed to data collection and writing the manuscript. RvD and JWD are guarantors.

Funding: None.

Competing interests: AMG is a consultant for Genentech, Kowa, Martek, Merck, and Merck/Schering-Plough, and serves on the board of directors for Aegerion and Arisaph. He is a member of DuPont's health advisory board and serves on the data safety monitoring board for Novartis. IS carried out consultancy work and receives support for research from Bristol-Myers Squibb. RGJW receives support for research from BristolMyers Squibb. HN has received travel grants and speaking honorariums from Sankyo. RHK has received research fees and speaking honorariums from Pfizer. PR has received research grant support from the National Heart Lung and Blood Institute, the National Cancer Institute, the Donald W Reynolds Foundation, the Leducq Foundation, Astra-Zeneca, Novartis, Merck, Abbott, Roche, and Sanofi-Aventis; consulting fees and lecture fees from Astra-Zeneca, Novartis, Merck-Schering Plough, Sanofi- 
Aventis, ISIS, and Vascular Biogenics; and is listed as a co-inventor on patents held by the Brigham and Women's Hospital that relate to the use of inflammatory biomarkers in cardiovascular disease. These patents have been licensed to Siemens and Astra-Zeneca.

Ethical approval: Not required.

1 American Heart Association. Heart disease and stroke statistics2008 update. 2008. www.americanheart.org/downloadable/heart/ 1200082005246HS_Stats\%202008.final.pdf.

2 Strippoli GF, Navaneethan SD, Johnson DW, Perkovic V, Pellegrini F, Nicolucci A, et al. Effects of statins in patients with chronic kidney disease: meta-analysis and meta-regression of randomised controlled trials. BMJ 2008;336:645-51.

3 Wei L, Ebrahim S, Bartlett C, Davey PD, Sullivan FM, MacDonald TM. Statin use in the secondary prevention of coronary heart disease in primary care: cohort study and comparison of inclusion and outcome with patients in randomised trials. BMJ 2005;330:821.

4 Law MR, Wald NJ, Rudnicka AR. Quantifying effect of statins on low density lipoprotein cholesterol, ischaemic heart disease, and stroke: systematic review and meta-analysis. BM/ 2003:326:1423.

5 Baigent C, Keech A, Kearney PM, Blackwell L, Buck G, Pollicino C, et al. Efficacy and safety of cholesterol-lowering treatment: prospective meta-analysis of data from 90,056 participants in 14 randomised trials of statins. Lancet 2005;366:1267-78.

6 Randomised trial of cholesterol lowering in 4444 patients with coronary heart disease: the Scandinavian Simvastatin Survival Study (4S). Lancet 1994;344:1383-9.

7 Executive Summary of the third report of the National Cholesterol Education Program (NCEP) Expert Panel on detection, evaluation, and treatment of high blood cholesterol in adults (Adult Treatment Panel III). JAMA 2001;285:2486-97.

8 Third report of the National Cholesterol Education Program (NCEP) Expert Panel on detection, evaluation, and treatment of high blood cholesterol in adults (Adult Treatment Panel III) final report. Circulation 2002;106:3143-421.

9 Graham I, Atar D, Borch-Johnsen K, Boysen G, Burell G, Cifkova R, et al. European guidelines on cardiovascular disease prevention in clinical practice: executive summary. Eur Heart J 2007;28:2375-414

10 Grundy SM, Cleeman II, Merz CN, Brewer HB Jr, Clark LT, Hunninghake DB, et al. Implications of recent clinical trials for the National Cholesterol Education Program Adult Treatment Panel III guidelines. Circulation 2004;110:227-39.

11 Abramson J, Wright JM. Are lipid-lowering guidelines evidencebased? Lancet 2007;369:168-9.

12 Walsh JM, Pignone M. Drug treatment of hyperlipidemia in women. JAMA 2004:291:2243-52.

13 Mills EJ, Rachlis B, Wu P, Devereaux PJ, Arora P, Perri D. Primary prevention of cardiovascular mortality and events with statin treatments: a network meta-analysis involving more than 65,000 patients. J Am Coll Cardiol 2008;52:1769-81.

14 Thavendiranathan P, Bagai A, Brookhart MA, Choudhry NK. Primary prevention of cardiovascular diseases with statin therapy: a metaanalysis of randomized controlled trials. Arch Intern Med 2006;166:2307-13.

15 Moher D, Cook DJ, Eastwood S, Olkin I, Rennie D, Stroup DF. Improving the quality of reports of meta-analyses of randomised controlled trials: the QUOROM statement. Quality of reporting of meta-analyses. Lancet 1999;354:1896-900.

16 Anderssen SA, Hjelstuen AK, Hjermann I, Bjerkan K, Holme I. Fluvastatin and lifestyle modification for reduction of carotid intimamedia thickness and left ventricular mass progression in drugtreated hypertensives. Atherosclerosis 2005;178:387-97.

17 Furberg CD, Adams HP Jr, Applegate WB, Byington RP, Espeland MA Hartwell T, et al. Effect of lovastatin on early carotid atherosclerosis and cardiovascular events. Asymptomatic Carotid Artery Progression Study (ACAPS) Research Group. Circulation 1994;90:1679-87.

18 Hedblad B, Wikstrand J, Janzon L, Wedel H, Berglund G. Low-dose metoprolol CR/XL and fluvastatin slow progression of carotid intimamedia thickness: main results from the Beta-Blocker CholesterolLowering Asymptomatic Plaque Study (BCAPS). Circulation 2001;103:1721-6.

19 Mercuri M, Bond MG, Sirtori CR, Veglia F, Crepaldi G, Feruglio FS, et al Pravastatin reduces carotid intima-media thickness progression in an asymptomatic hypercholesterolemic Mediterranean population: the Carotid Atherosclerosis Italian Ultrasound Study. Am J Med 1996;101:627-34.

20 Mohler ER 3rd, Hiatt WR, Creager MA. Cholesterol reduction with atorvastatin improves walking distance in patients with peripheral arterial disease. Circulation 2003;108:1481-6.

21 Salonen R, Nyyssonen K, Porkkala E, Rummukainen J, Belder R, Park JS, et al. Kuopio Atherosclerosis Prevention Study (KAPS). A population-based primary preventive trial of the effect of LDL lowering on atherosclerotic progression in carotid and femoral arteries. Circulation 1995;92:1758-64.

22 Sawayama Y, Shimizu C, Maeda N, Tatsukawa M, Kinukawa N, Koyanagi S, et al. Effects of probucol and pravastatin on common carotid atherosclerosis in patients with asymptomatic hypercholesterolemia. Fukuoka Atherosclerosis Trial (FAST). J Am Coll Cardiol 2002;39:610-6.

23 Zanchetti A, Crepaldi G, Bond MG, Gallus G, Veglia F, Mancia G, et al. Different effects of antihypertensive regimens based on fosinopril or hydrochlorothiazide with or without lipid lowering by pravastatin on progression of asymptomatic carotid atherosclerosis: principal results of PHYLLIS-a randomized double-blind trial. Stroke 2004;35:2807-12

24 Holdaas H, Fellstrom B, Jardine AG, Holme I, Nyberg G, Fauchald P, et al. Effect of fluvastatin on cardiac outcomes in renal transplant recipients: a multicentre, randomised, placebo-controlled trial. Lancet 2003;361:2024-31.

25 Effects of pravastatin in patients with serum total cholesterol levels from 5.2 to $7.8 \mathrm{mmol} /$ liter (200 to $300 \mathrm{mg} / \mathrm{dl}$ ) plus two additional atherosclerotic risk factors. The Pravastatin Multinational Study Group for Cardiac Risk Patients. Am J Cardiol 1993;72:1031-7.

26 Pravastatin use and risk of coronary events and cerebral infarction in Japanese men with moderate hypercholesterolemia: the Kyushu Lipid Intervention Study. J Atheroscler Thromb 2000;7:110-21.

27 Asselbergs FW, Diercks GF, Hillege HL, van Boven AJ, Janssen WM, Voors AA, et al. Effects of fosinopril and pravastatin on cardiovascular events in subjects with microalbuminuria. Circulation 2004;110:2809-16.

28 Jadad AR, Moore RA, Carroll D, Jenkinson C, Reynolds DJ, Gavaghan DJ, et al. Assessing the quality of reports of randomized clinical trials: is blinding necessary? Control Clin Trials 1996;17:1-12.

29 DerSimonian R, Laird N. Meta-analysis in clinical trials. Control Clin Trials 1986;7:177-88.

30 Sever PS, Dahlof B, Poulter NR, Wedel H, Beevers G, Caulfield M, et al. Prevention of coronary and stroke events with atorvastatin in hypertensive patients who have average or lower-than-average cholesterol concentrations, in the Anglo-Scandinavian Cardiac Outcomes Trial—Lipid Lowering Arm (ASCOT-LLA): a multicentre randomised controlled trial. Lancet 2003;361:1149-58.

31 Higgins JP, Thompson SG, Deeks JJ, Altman DG. Measuring inconsistency in meta-analyses. BMJ 2003;327:557-60.

32 Egger M, Davey Smith G, Schneider M, Minder C. Bias in metaanalysis detected by a simple, graphical test. BMJ 1997;315:629-34.

33 Ford I, Blauw GJ, Murphy MB, Shepherd J, Cobbe SM, Bollen EL, et al. A Prospective Study of Pravastatin in the Elderly at Risk (PROSPER) screening experience and baseline characteristics. Curr Contro Trials Cardiovasc Med 2002;3:1-8.

34 Ford I, Murray H, Packard CJ, Shepherd J, Macfarlane PW, Cobbe SM Long-term follow-up of the West of Scotland Coronary Prevention Study. N Engl J Med 2007;357:1477-86

35 Strandberg TE, Pyorala K, Cook TJ, Wilhelmsen L, Faergeman O, Thorgeirsson G, et al. Mortality and incidence of cancer during 10 year follow-up of the Scandinavian Simvastatin Survival Study (4S). Lancet 2004;364:771-7.

36 Braunwald E, Domanski MJ, Fowler SE, Geller NL, Gersh BJ, Hsia J, et al. Angiotensin-converting-enzyme inhibition in stable coronary artery disease. N Engl J Med 2004;351:2058-68.

37 Fox KM, Henderson JR, Bertrand ME, Ferrari R, Remme WJ, Simoons ML. The European trial on reduction of cardiac events with perindopril in stable coronary artery disease (EUROPA). Eur Heart J 1998;19(suppl J):J52-5.

Accepted: 4 February 2009 